\title{
The Utilization of New Media in Online Public Relations Activities Among The Public Relations Practitioners
}

\author{
Nik Adzrieman Abd Rahman \\ \{ adzrieman@uum.edu.my \} \\ Universiti Utara Malaysia
}

\begin{abstract}
The Internet has become a vital tool for PR because it is critical for most people. The utilization of online PR especially social media has increasingly become an integration function of organizational communication and provides several communication platforms to reach an organization's publics and developing dialogs and increase the online presence of an organization. Moreover, the usage of social media comprises unique ways for boosting an organization and its products or services and for increasing its visibility in the virtual environment and Stakeholders can communicate among and between each other concerning an organization in very public, fast, cheap and effective ways. This paper intends to show that the usage of online PR tools through PR practitioners, especially social media tools. This paper is intended to understand value of social media for PR, the benefits of social media for publics and for organizations and the possible implications of current social media use for PR. The review of the literature suggests the dire research needs to empirical data exists on the ways in which PR practitioners are utilizing social media and how this utilization is influencing PR practices.
\end{abstract}

Keywords: New Media, Online Public Relations, Social Media, Public Relations Practitioners, Online Public Relations Tools, Utilizations, Activities.

\section{Introduction}

There is a commonly acceptable presumption that the Internet's importance as a medium for commerce and communication has grown progressively and has increased regarding corporate communication and marketing including advertising, market research, and retailing since the Internet first began operating for commercial activity in 1994 [1]. So, the Internet presents new opportunities and efficiencies that are unavailable by means other media and sales channels [2]. In addition, Internet technology and the tools accompanying that technology increase stakeholder strength by facilitating the communication between and among stakeholder groups [3], [4]. Thus, Stephens [5] believed that the information "pours out of digital spigots" and news now arrives "astoundingly fast from a surprising number of directions" (p. 35) and, furthermore, that information is often free.

According to Taylor and Kent [6], anyone with a computer connected to the Internet can publish information for potential global consumption and clearly the Internet is revolutionizing many features of PR research and practice. Internet technology provides PR with an unparalleled opportunity to collect information and data, monitor public opinion, and 
engage in a direct dialogue with communities about a various of issues [6], [7]. In addition, Internet technologies allow PR professionals to achieve customization strategies by offering stakeholders, which include members of the news media, with online options for configuring information produced for PR aims [8].

The scholars unanimously agreed that the new media innovations have changed many aspects of PR practice [3], [9]-[15] were among the first to discover the utilization of new media in the practice of PR and in praising the virtue of the two-way interactive capacity of the World Wide Web [16]. In particular, social media are fast, cheap and interactive channels to reach targeted audiences. In PR, social media - those chat platforms that are reflected in asynchronous conversations and the sharing of user-generated materials using the Web 2.0 environment [17].

Meanwhile, Wright and Hinson [18] pointed out that PR practitioners strongly believe that social media are changing the way in which PR is practiced, and their utilization is positively correlated with the perceived strategic impacts of PR in organizations [19]. A pervasive discourse exists in the PR literature that using social media in PR has positive consequences [19]-[22]. Therefore, the practical rate of the utilization social media in Phase increased across the globe [16], [23]-[33].

Because of the profound influence of social media in the practice of PR, Valentini and Kruckeberg [17] have argued that social media should reside at the heart of PR activities because they can promote an organization's relationships by means of improving community relations. In addition, [34], [35] said that social media enable the development of a relationship between marketing and PR by enabling a greater capacity for interaction and the cultivation of relationships. Furthermore, the utilization of social media and interactive applications help in realizing the two-way symmetrical model of communication as explicated in excellence theory [36], [37]. In addition, social media promote, quick, fast, instant discussion and keep relationships at an additional superficial level [38].

Therefore, there is a need for a substantial study to investigate the usage of online PR tools through PR practitioners, especially social media tools and how these tools are properly employed to keep up with the huge technological development witnessed by all aspect the life Which automatically reflected in PR activities and practices, the understand value of social media for PR , the benefits of social media for publics and for organizations; and the possible implications of current social media use for PR. This article offers the literature review that calls for research to undertake study on How PR practitioners use the tools of the social media in their practices, their importance, the challenges they face, the types of media tools used and How evolved the use of these means with the evolution of time.

Evidently, there have been very little empirical data exists on the ways in which PR practitioners are utilizing online PR and how this utilization is influencing PR practices [39]. Despite the popularity of social media studies related to PR, Macnamara and Zerfass [40] noted that significant gaps remain in the knowledge related to how organizations are using social media and how these valuable new communication channels either can or should be utilized in the context of PR .in addition, Several case studies have suggested that reasonable bases for concern exist because some organizations are trying to engage in public communication in the Web 2.0 environment utilizing one-way information transmission and a control paradigm of communication reminiscent of the characteristics of mass media and Web 1.0 [41]. Furthermore, in some instances, case studies have shown social media and social networks are adopting either inappropriate or unethical practices. This paper believes that without reliable measurement of how PR practitioners can use online PR tools and know how 
to use them optimally, their use of these tools indiscriminately and without knowledge and awareness will be hardly feasible and may have a negative impact.

\section{Results}

\subsection{The Impact of The Utilization Online PR in Organizations}

Online PR is an extremely crucial new stage in PR development. It has completely altered the way of working and the content of work in PR and has permeated the PR work of almost every organization [41]. Furthermore, online PR helps to solve many problems quickly and efficiently especially in time of crises. In addition, online PR helps in data gathering and research and in monitoring a corporate image through online newspapers and all types of electronic publications. Also, suggestion boxes and comments and questions of visitors gathered through an organization's website are major sources for research and data gathering and provide feedback for PR activities, for PR planning and for PR programming and are a good source for decision making [10].

Generally, online PR has altered the speed, efficiency and ease with which organizations and institutions deal with the public as online PR has allowed an organization to remain informed about the public's views and reactions. This means that they can manage any crisis that they face quickly. Kirat [10] noted that online communication serves all varieties of tasks and types of content in organizational communication. Online has become the closest that an organization can come to one channel carrying plain text through multimedia. For example, email is a primary internal and external communications tool and to national media. PR departments can send images and text through email so online newsrooms are essential for companies [10], [42]. Also, web pages have shown a great progress for better design possibilities, the integration of multimedia elements and a larger interaction between a user and an organization [42].

Moreover, Naude, Froneman, and Atwood [43] have pointed out that many companies and organizations already were devoting particular sections of their websites typically called "online press rooms," for communicating with the media. From this specific area, a company can provide any sort of news to the press, making it easy for journalists to gather information about a company and simultaneously serving as a channel for information requests. This clearly offers advantages for organizations having limited resources. Bortree and Seltzer [46], Cooley [44], and Grunig [35] all noted many benefits existed for using online PR by organizations, especially in increasing interactions with publics. These led to improving the corporate image, setting corporate agendas reflecting the needs of the public, and ease in collecting and analysing public opinion and increasing corporate accountability (Cooley, 1999). McAllister and Taylor [7] added that other advantages existed like collecting information, monitoring public opinion on issues, and engaging in direct dialogues with publics about various issues.

\subsection{The Utilization of Online PR Tools Among Practitioners}

Research has been undertaken to understand the utilization of online PR. For example, Macnamara [41] found that PR units in organizations and consultancies are using social media (social networks, LinkedIn, Facebook, and YouTube) in approaches exploiting their 
interactive two-way communication capabilities and realizing best practices as dialogic models in ways that the excellence theory of PR has described. Kelleher and Sweetser [45] agreed with Macnamara [41] that the utilization of social media is essential to the practice of PR itself because of 2-way communication, interactivity, dialogue, and engagement.

Similarly, in a study of Malaysian PR practitioners, Gabriel and Koh [46] found that $84.6 \%$ of the surveyed PR practitioners were using social media to communicate directly with their stakeholders about their organizations, and that such communication included announcements, mission statements, the latest business news, value statements, and updates. Social networking sites were the most used social media as $26(100 \%)$ of respondents utilized them. Of the respondents $16(72.7 \%)$ agreed that social media communication with their stakeholders produced the preferred results. These desired results included growth in awareness, in branding and in the popularity of the organization as well as an increase in sales [46]. In general, research has indicated that the primary purpose of using online PR is to communicate with internal and external public and customers, to establish two-way communication capabilities, and to achieve brand awareness and stimulate sales. The results of which are improved reputation and increased loyalty to these organizations.

However, other research has found the poor use and effectiveness of social media as a dialogic tool so far by practitioners and that obstacles prevent them from using social media [47]-[50]. Scholars have found that several factors affect the non-utilization of social media. Gordon [51], Joo and Teng [52].

Hakeas and Komodromos [53] suggested that PR and marketing practitioners utilize blogs, forums, social networks more often today in marketing PR because blogs allow them to respond to online opinions or criticisms regarding their organizations or their clients. Also, the use of social media in the marketing PR campaigns can help to build and maintain relationships between an organization and its various publics [54]. Another study conduct by Shahid, Akram, Zulqarnain \& Hashmi [55] showed that majority of PRO professionals use social media which increase PR of institutions and improve the positive image building and good will of the institute. By contrast, Waters, Burnett, Lamp, and Lucas [56] found that, even though non-profits are transparent in their Facebook profiles, they do not use these sites to their full potential to inform others, and have these people become more involved with organizational activities. The findings indicated that non-profits must do more to enhance their information dissemination and involvement strategies.

El-Kasim and Idid [57] affirmed the utilization of social media in PR practice in developed countries and in developing countries. Thus, it has become an imperative for PR practitioners to utilize online PR in their organizations to provide and shape cordial relationships with their strategic constituents. Kang and Norton [58] and Curtis et al. [59] concluded that online PR was an important PR tool and an organization could follow the views of the public, the reactions of action and criticism more easily through its use.

Additionally, Wigley and Zhang [60] surveyed members of the PR Society of American. Their results confirmed that utilizing online PR was seen as a useful tool especially in a crisis. Almost half of the respondents of the 251 respondents $(48 \%)$ reported that they had incorporated the social media into their crisis plans and most said that they had included Twitter in their crisis planning, mostly for distribution.

Organizations today are forced to utilize online PR in their strategic plans in the management of crises because of the change in the methods of practicing PR when the spread of social media. A successful organization is one that can reach the masses in a fast, effective, and integrated way, and social media is among the easiest and most effective ways, especially with respect to the young who use the media frequently. 
Furthermore, Porter, Sweetser, Trammell, Chung, and Kim [25] asserted that PR practitioners who utilize new technologies such as blogging are perceived as having more power in organizations because these users are prepared to be industry leaders and to use new tools to contact target publics better. In addition, Dornyo [61] found that PR practitioners in Ghana utilize Facebook pages for their organizations because they consider Facebook to be an effective tool to communicate with their target audiences. Furthermore, the utilization of Facebook pages of most organizations that were studied were very interactive, and feedback was used to enhance relationship between the organizations and their publics. Despite all its problems, all respondents endorsed Facebook as an effective communication tool and highly recommended it for PR practitioners who were not utilizing it.

With respect to higher education, Moyo and Moqasa [62] who studied a university in Cape Town South Africa, argued that the utilization of ICTs as a PR tools has become a vital instrument in institutions of higher learning. They found that ICTs played a significant role for the communication division at the university because they enabled the department to be in touch with its publics and work efficiently. When used competently, Moyo and Moqasa [62] argued that these ICTs would create well organized, reputable communication, and intensify the division's efficiency.

\subsection{Online PR Tools}

Different views exist concerning which online PR tools work best. Prescott [63] said that the best tools for online PR are corporate websites, online services and multimedia, electronic mail, and the World Wide Web. Dumitru, Negricea and Gogonea [64] said online PR tools include websites, email, forums, banners and newsletters. While Kisiołek, Kolmasiak and Budzik, [65] insisted that the online PR tools are the www sites, electronic mail, email and discussion groups, Internet conference newsletters and services sponsoring. In addition, Start [66] said that online PR includes the Internet, the World Wide Web, email, chats and instant messaging, Internet forums, intranets and extranets, content management systems and Wikis, and blogs, feeds and really simple syndication (RSS). As well, Ewing, Juba and Garden, (2008) asserted that blogs, e-newsletters, online media room, podcasts, webcasts, and wikis and are the most popular online PR tools. Du Plessis, [67] argued that the World Wide Web, corporate websites, email and online services are the most important tools. Holtz [68] pointed to e-mail, the World Wide Web and Permission-Driven Communication were online PR tools. Furthermore, Kirat [10] focused on electronic newspapers, newsrooms, online publications, press releases and web sites as essential online PR tools.

These various lists mean that the meaning of essential online PR tools differs from one researcher to another. In considering these enumerations, the time period in which these studies were conducted has a great relationship with the evolution of the tools. Recently, for example, Bashir and Aldaihani [69] argued that twitter and Instagram were the new online PR tools. In addition, several theorists and scholars have insisted that these tools have offer the most advantages for corporate online communication [70]-[75]. Table 1 Shows online PR tools based on the studies under title online PR.

Table 1. Online PR tools based on the studies under title online PR

\begin{tabular}{lcc}
\hline Online PR tools & Author(s) & Year \\
\hline Multimedia electronic mail & Prescott & $\mathbf{1 9 9 7}$ \\
Online services & & \\
Website & & \\
World Wide Web & & \\
\hline
\end{tabular}




\begin{tabular}{|c|c|c|}
\hline $\begin{array}{l}\text { E-mail } \\
\text { Permission-Driven Communication } \\
\text { World Wide Web }\end{array}$ & Holtz & 2002 \\
\hline $\begin{array}{l}\text { Discussion groups } \\
\text { E-mail } \\
\text { Internet conference } \\
\text { Newsletters and services sponsoring } \\
\text { www site }\end{array}$ & $\begin{array}{l}\text { Kisiołek, Kolmasiak, } \\
\text { \& Budzik, }\end{array}$ & 2003 \\
\hline $\begin{array}{l}\text { Corporate website } \\
\text { E-mail } \\
\text { Online services } \\
\text { World Wide Web }\end{array}$ & Du Plessis & 2005 \\
\hline $\begin{array}{l}\text { E-mail } \\
\text { FTP or file transfer protocol } \\
\text { Internet } \\
\text { World Wide Web } \\
\text { Chats and instant messaging } \\
\text { Internet forums } \\
\text { Intranets and extranets } \\
\text { Content management systems } \\
\text { Wikis, Blogs, Tracking and pings } \\
\text { Feeds and really simple syndication (RSS) }\end{array}$ & Start & 2006 \\
\hline $\begin{array}{l}\text { Electronic newspapers } \\
\text { News rooms } \\
\text { Online publications } \\
\text { Web site and Press releases }\end{array}$ & Kirat & 2007 \\
\hline $\begin{array}{l}\text { Blogs } \\
\text { E-newsletters } \\
\text { Online media room } \\
\text { Podcasts } \\
\text { Search Engine Optimization } \\
\text { Webcasts } \\
\text { Wikis and Web site design and content } \\
\text { development }\end{array}$ & Ewing, Juba \& Garden & 2008 \\
\hline $\begin{array}{l}\text { Banners and Newsletter } \\
\text { E-mail } \\
\text { Forum } \\
\text { Website }\end{array}$ & $\begin{array}{c}\text { Dumitru, Negricea \& } \\
\text { Gogonea }\end{array}$ & 2011 \\
\hline $\begin{array}{l}\text { Instagram } \\
\text { Twitter }\end{array}$ & Bashir \& Aldaihani, & 2017 \\
\hline
\end{tabular}

Thus, in general, after reviewing the literature, no clear and explicit definition of online PR and no identification of the tools or forms used to achieve the objectives of the organization through online PR exist. The literature shows that each study has named its own set of tools. This disparity may be due to the constant and rapid change of these tools over time because modern technology allows for constant innovation and renewal, which means that examinations must be forward looking to see what is new in the world of technology and what changes will occur in the practice of PR and communication.

Thus, based on what has been mentioned previously, this current article defines online PR in this research context as professional and technical services that depend on Internet technology and take advantage of all its characteristic such as speed, spread, low cost and ease of use to help an organization to improve, strengthen, develop and deepen the 
relationship between the internal and external audiences of the organization and enhance the image of this organization as well as the well-known traditional tools of PR, to become the interaction between the organization and the masses in two way communications and in order for this interaction to succeed, the optimal utilization must be known for these means and their suitability to the public and the environment in which PR are practiced.

Moreover, the current article observed that online PR studies include everything that applies and uses the Internet and its tools including the present social media in all its forms (blogs, forums, websites and email, etc.) and those that will emerge in the future by means of new technological developments.

\subsection{The Challenges Face PR Practitioners When Using Online PR Tools}

PR practitioners faces many challenges in employing these digital tools. Practitioners must keep abreast of technological developments to quickly disseminate information and to be able to respond quickly, effectively and accurately. The first challenge of utilizing these tools was discovering how to eliminate time-intensive, repetitive tasks such as stuffing envelopes with press releases or faxing them to hundreds of media outlets one at a time [2], [76]. Aronson, Spetner, and Ames [76] added that additional challenge the PR revolution faced was discovering how to go beyond mere time and money savings to develop new methods of communicating effectively with customers, employees, investors, media, and the public. Aronson, Spetner, and Ames (2010) noted that applied creativity and PR training, combined with skills and computer know-how, have facilitated new ways of communicating a company's image, the benefits of a product, or the community objectives of an organization. Consequently, the demands of this stage are related to the harnessing of the potentialities of email, interactive communication, and handheld devices linked to the convergence of computers with digital media players, telephones, and television, to communicate personally with hundreds, thousands, or potentially even millions simultaneously [76]. According to Karim and Ghareb [77], other challenges like credibility, multiple channels, measuring the impact of social media and two-way communications exist.

\section{Conclusion}

In recent years, the revolution of Internet and new media especially social media changed the PR practices around the world to enter a new transitional phase despite all the challenges faced PR practitioners.

Generally, a PR practitioner utilizes online PR because the Internet is valuable to people, and PR is a competitive field. and there are many advantages of the utilization online PR include message accuracy, precision, low cost, improving the positive image of the institution, maintaining relations with the public and crisis management, etc. Moreover, a PR practitioner who does not communicate effectively with online communities can no longer shape or maintain the desired public image effectively results from many factors, including fear of taking responsibility, official reprimands, and criticism from the public and the inability to deal with rapid developments in the social media. Also, organizational policy organization, which is often the reflection of state policy, play an essential role in allowing freedom to expression and participation. Also, the studies have focused on the utilization of certain tools of the social media that been instrumental in providing the connections between PR 
practitioners and the public, and the most important of these tools are blogs, forums, Facebook, and Twitter. Eventually, the democracy of the Internet has forced these specialists to compete with the entire world.

\section{References}

[1] W. Hanson and K. Kalyanam, Principles of Internet marketing. South-Western College Publishing.

[2] P. Christ, "Internet technologies and trends transforming public relations," J. Website Promot., vol. 1, no. 4, pp. 3-14.

[3] P. Hurme, "Online PR: emerging organisational practice," Corp. Commun. An Int. J., vol. 6, no. 2, pp. 71-75.

[4] A. J. A. M. Van Deursen, C. L. Bolle, S. M. Hegner, and P. A. M. Kommers, "Modeling habitual and addictive smartphone behavior: The role of smartphone usage types, emotional intelligence, social stress, self-regulation, age, and gender," Comput. Human Behav., vol. 45, pp. 411-420, 2015.

[5] M. Stephens, "Beyond News. Columbia Journalism Review." .

[6] M. Taylor and M. L. Kent, "Taxonomy of mediated crisis responses," Public Relat. Rev., vol. 33, no. 2, pp. 140-146.

[7] S. M. McAllister and M. Taylor, "Community college web sites as tools for fostering dialogue," Public Relat. Rev., vol. 33, no. 2, pp. 230-232.

[8] P. Christ, "Achieving seamless website transformation: Promotional implications of static versus dynamic websites," J. Website Promot., vol. 1, no. 2, pp. 97-109.

[9] M. A. Johnson, "Public relations and technology: Practitioner perspectives," J. Public Relations Res., vol. 9, no. 3, pp. 213-236.

[10] M. Kirat, "Promoting online media relations: Public relations departments' use of Internet in the UAE," Public Relat. Rev., vol. 33, no. 2, pp. 166-174.

[11] H. Stuart and C. Jones, "Corporate branding in marketspace," Corp. Reput. Rev., vol. 7, no. 1, pp. 84-93.

[12] J. Sullivan, "What are the functions of corporate home pages?," J. World Bus., vol. 34, no. 2, pp. 193-210.

[13] L. Ye and E. J. Ki, "The status of online public relations research: An analysis of published articles in 1992-2009," J. Public Relations Res., vol. 24, no. 5, pp. 409434.

[14] W. T. Coombs, "The Internet as potential equalizer: New leverage for confronting social irresponsibility," Public Relat. Rev., vol. 24, no. 3, pp. 289-303.

[15] R. L. Heath, "New communication technologies: An issues management point of view," Public Relat. Rev., vol. 24, no. 3, pp. 273-288.

[16] M. Taylor and M. L. Kent, "Anticipatory socialization in the use of social media in public relations: A content analysis of PRSA's Public Relations Tactics," Public Relat. Rev., vol. 36, no. 3, pp. 207-214.

[17] C. Valentini and D. Kruckeberg, "New media versus social media: A conceptualization of their meanings, uses, and implications for public relations," in New media and public relations, pp. 3-12.

[18] D. K. Wright and M. D. Hinson, "Examining social and emerging media use in public relations practice: A ten-year longitudinal analysis," Public Relat. J., vol. 9, no. 2, pp. $1-26$.

[19] N. Eyrich, M. L. Padman, and K. D. Sweetser, "PR practitioners' use of social media 
tools and communication technology," Public Relat. Rev., vol. 34, no. 4, pp. 412-414.

[20] J. H. Shin, H. Carithers, S. Lee, M. Graham, and N. Hendricks, "The current trends in social media usage at corporations: Analysis of Facebook fan pages of fortune 500 companies. Social media and strategic communications.” p. 62.

[21] R. W. Lariscy, E. J. Avery, K. D. Sweetser, and P. Howes, "An examination of the role of online social media in journalists' source mix," Public Relat. Rev., vol. 35, no. 3, pp. 314-316.

[22] D. K. Wright and M. D. Hinson, "An updated examination of social and emerging media use in public relations practice: A longitudinal analysis between 2006 and," Public Relat. J., vol. 7, no. 3, pp. 1-39.

[23] L. M. Sallot, L. V Porter, and C. Acosta-Alzuru, "Practitioners' web use and perceptions of their own roles and power: A qualitative study," Public Relat. Rev., vol. 30, no. 3, pp. 269-278.

[24] L. Porter, K. Sweetser, and D. Chung, "The blogosphere and public relations: Investigating practitioners' roles and blog use," J. Commun. Manag., vol. 13, no. 3, pp. 250-267.

[25] L. V Porter, K. D. S. Trammell, D. Chung, and E. Kim, "Blog power: Examining the effects of practitioner blog use on power in public relations," Public Relat. Rev., vol. 33, no. 1, pp. 92-95.

[26] M. Diga and T. Kelleher, "Social media use, perceptions of decision-making power, and public relations roles," Public Relat. Rev., vol. 35, no. 4, pp. 440-442.

[27] B. Solis and D. K. Breakenridge, "Putting the public back in public relations: How social media is reinventing the aging business of PR. FT Press," Public Relat. Rev., vol. 36, no. 1, pp. 90-92.

[28] Y. Jin and B. F. Liu, "The blog-mediated crisis communication model: Recommendations for responding to influential external blogs," J. Public Relations Res., vol. 22, no. 4, pp. 429-455.

[29] P. J. Kitchen and A. Panopoulos, "Online public relations: The adoption process and innovation challenge, a Greek example," Public Relat. Rev., vol. 36, no. 3, pp. 222229.

[30] P. Steyn, E. Salehi-Sangari, L. Pitt, M. Parent, and P. Berthon, "The Social Media Release as a public relations tool: Intentions to use among B2B bloggers," Public Relat. Rev., vol. 36, no. 1, pp. 87-89.

[31] M. Toledano, "Professional competition and cooperation in the digital age: A pilot study of New Zealand practitioners," Public Relat. Rev., vol. 36, no. 3, pp. 230-237.

[32] T. K. Tomasello, Y. Lee, and A. P. Baer, "New media'research publication trends and outlets in communication, 1990-2006," new media Soc., vol. 12, no. 4, pp. 531548.

[33] B. P. Venter, "Views of PRISA-members on South African public relations: An exploration," Public Relat. Rev., vol. 36, no. 3, pp. 281-284.

[34] B. G. Smith, "Exploring Social Media Empowerment of Public Relations: A Case Study of Health Communication Practitioner Roles and the Use of Social Media," in Social Media and Strategies Communications, Palgrave Macmillan UK, pp. 101-118.

[35] J. E. Grunig, "Paradigms of global public relations in an age of digitalisation," Prism, vol. 6 , no. 2 , pp. $1-19$.

[36] J. E. Grunig and F. C. Repper, "Strategic management, publics, and issues. Excellence in public relations and communication," management, vol. 73, no. 1, pp. 117-157.

[37] J. E. Grunig, L. A. Grunig, K. Sriramesh, Y. H. Huang, and A. Lyra, "Models of 
public relations in an international setting," J. public relations Res., vol. 7, no. 3, pp. 163-186.

[38] D. Goldstraw, Can PR Practitioners Build Positive Journalist Relationships Via Social Media?. Public Relations, Values and Cultural Identity. Brussels: Peter Lang.

[39] P. Robson, "Time to bridge the gaps: issues with current social media research in public relations," in Australian and New Zealand Communication Association Conference (ANZCA, pp. 1959-13.

[40] J. Macnamara and A. Zerfass, "Social media communication in organizations: The challenges of balancing openness, strategy, and management," Int. J. Strateg. Commun., vol. 6, no. 4, pp. 287-308.

[41] H. Li, J. Ma, and W. Duan, "The Standardization of Online Public Relations Is Imperative," in Management and Service Science (MASS), 2010 International Conference on, pp. 1-4.

[42] G. H. Alfonso and R. de Valbuena Miguel, "Trends in online media relations: Webbased corporate press rooms in leading international companies," Public Relat. Rev., vol. 32, no. 3, pp. 267-275.

[43] A. M. Naude, J. D. Froneman, and R. A. Atwood, "The use of the internet by ten South African non-governmental organizations - a public relations perspective," Public Relat. Rev., vol. 30, no. 1, pp. 87-94.

[44] T. Cooley, "Interactive communication--public relations on the Web," Public Relations $Q$. , vol. 44, no. 2, p. 41.

[45] T. Kelleher and K. Sweetser, "Social media adoption among university communicators," J. Public Relations Res., vol. 24, no. 2, pp. 105-122.

[46] S. P. Gabriel and C. H. Koh, "Social media use by public relations practitioners in Malaysia: An exploratory study," J. Dev. Areas, vol. 50, no. 5, pp. 469-477.

[47] S. M. McAllister-Spooner, "Fulfilling the dialogic promise: A ten-year reflective survey on dialogic Internet principles," Public Relat. Rev., vol. 35, no. 3, pp. 320-322.

[48] M. L. Kent, "Using social media dialogically: Public relations role in reviving democracy," Public Relat. Rev., vol. 39, no. 4, pp. 337-345.

[49] E. J. Sommerfeldt, M. L. Kent, and M. Taylor, "Activist practitioner perspectives of website public relations: Why aren't activist websites fulfilling the dialogic promise?," Public Relat. Rev., vol. 38, no. 2, pp. 303-312.

[50] A. M. Lee, H. de Zúñiga, R. Coleman, and T. J. Johnson, The dialogic potential of social media: Assessing the ethical reasoning of companies' public relations on Facebook and Twitter. Ethical practice of social media in public relations. New York, NY: Routledge.

[51] J. Gordon, "Use, Value and Impact of Social Media on Public Relations Practitioners in the Fox Cities (Unpublished doctoral dissertation)." .

[52] T. M. Joo and C. E. Teng, "Use of Social Media in PR: A Change of Trend," World Acad. Sci. Eng. Technol. Int. J. Humanit. Soc. Sci., vol. 3, no. 4.

[53] M. Komodromos, "A study of PR practitioners use of social media tools in cyprus," $J$. Dev. Entrep., vol. 19, no. 2, p. 1450011.

[54] D. Halkias and M. Komodromos, "Social media and the practice of marketing public relations in Cyprus," Int. J. Technol. Enhanc. Learn., vol. 8, no. 2, pp. 103-113.

[55] K. Shahid, E. Akram, W. Zulqarnain, and N. U. Hashmi, "August). Reshaping Public Relation through Social Media: A Study on Influence and Challenges in Universities," in Indonesia International Graduate Conference on Communication (IndoIGCC) Proceeding, vol. 2, pp. 740-752. 
[56] R. D. Waters, E. Burnett, A. Lamm, and J. Lucas, "Engaging stakeholders through social networking: How nonprofit organizations are using Facebook," Public Relat. Rev., vol. 35, no. 2, pp. 102-106.

[57] M. El-Kasim and S. A. Idid, "PR Practitioners' Use of Social Media: Validation of an Online Relationship Management Model Applying Structural Equation Modeling," J. Komunikasi, Malaysian J. Commun., vol. 33, no. 1.

[58] S. Kang and H. E. Norton, "Colleges and universities' use of the World Wide Web: A public relations tool for the digital age," Public Relat. Rev., vol. 32, no. 4, pp. 426428.

[59] L. Curtis et al., "Adoption of social media for public relations by nonprofit organizations," Public Relat. Rev., vol. 36, no. 1, pp. 90-92.

[60] S. Wigley and W. Zhang, "A study of PR practitioners' use of social media in crisis planning," Public Relat. J., vol. 5, no. 3, pp. 1-16.

[61] P. Dornyo, "The use of Facebook in organizational public relations practice: a study of selected organization in Ghana," Int. J. ICT Manag., vol. 2, no. 2, pp. 2026-6839.

[62] L. Moyo and N. A. Moqasa, "The Effectiveness of ICTs as a Public Relations Tool in Institutions of Higher Learning: A Case of University of," J. Commun., vol. 7, no. 2, pp. 274-286.

[63] M. B. Prescott, "Understanding the Internet as an innovation," Ind. Manag. Data Syst., vol. 97, no. 3, pp. 119-124.

[64] N. R. Dumitru, C. I. Negricea, and M. R. Gogonea, "Specific public relations tools used in online communications by tourism companies," USV Ann. Econ. Public Adm., vol. 10 , no. 1 , pp. 9-18.

[65] A. Kisiołek, C. Kolmasiak, and R. Budzik, "Public Relations on the Internet on the Examples of the Metallurgical," in Industry in Poland and in the World. Metalurgija, vol. 42, no. 2, pp. 117-121.

[66] W. T. Start, "Perhaps a colorful vignette is a good place to start a book on online public relations.".

[67] C. Du Plessis, "A theoretical framework of corporate online communication: a marketing public relations (MPR) perspective (Doctoral dissertation)." .

[68] S. Holtz, Public relations on the Net: winning strategies to inform and influence the media, the investment community, the government, the public, and more! Amacom Div American Mgmt Assn.

[69] M. Bashir and A. Aldaihani, "Public relations in an online environment: Discourse description of social media in Kuwaiti organizations," Public Relat. Rev., vol. 43, no. 4, pp. 777-787.

[70] D. F. Angell and B. Heslop, The Internet business companion: growing your business in the electronic age. Addison-Wesley Longman Publishing Co., Inc.

[71] R. Bobbitt, “An Internet primer for public relations,” Public Relations Q., vol. 40, no. 3, p. 27.

[72] D. S. Janal, Online Marketing Handbook: How to Sell, Advertise, Publicize and Promote Your Products and Services on the Information Superhighway. John Wiley \& Sons, Inc.

[73] P. Herbig and B. Hale, "Internet: the marketing challenge of the twentieth century," Internet Res., vol. 7, no. 2, pp. 95-100.

[74] P. J. Kitchen, Marketing communications: Principles and practice. Cengage Learning EMEA.

[75] K. M. Bayne, The Internet Marketing Plan: The Complete Guide to Instant Web 
Presence with Cdrom. John Wiley \& Sons, Inc.

[76] M. Aronson, D. Spetner, and C. Ames, The public relations writer's handbook: the digital age. John Wiley \& Sons.

[77] S. H. Karim and M. I. Ghareb, "The Impact of Technology Complexity on Public Relations," RA J. Appl. Res. 